\title{
BoOKs ReCEIVED/ LivRES ReÇUS
}

Bartley, Mel. Health Inequality: An Introduction to Concepts, Theories, and Methods. Hoboken, NJ: Blackwell John Wiley, 2016. \$35.95, 244 pp., paper (9780745691107)

Barton, Bernadette. Stripped: More Stories from Exotic Dancers. New York: New York University Press, 2017. \$26.00, 256 pp., paper (9781479897285)

Bauman, Zygmunt. Retrotopia. Cambridge and Malden: Polity Press, 2017. 180 pp., \$23.95 paper (978-1-5095-1531-8)

Bergmann, Sigurd. Religion, Space and the Environment. Herndon, VA: Transaction Publishers, 2016. 479 pp., \$37.95 hardcover (9781412862943)

Best, Amy. Fast Food Kids: French Fries, Lunch Lines and Social Ties. New York: New York University Press, 2017. 244 pp., \$26.00 paper (9781479802326)

Blaikie, Norman and Jan Priest. Social Research: Paradigms in Action. Hoboken, NJ, Blackwell John Wiley, 2017. 280 pp., \$31.95 paper (9780745671857)

Bouchard, Gérard. Social Myths and Collective Imaginaries. Translated by Howard Scott. Toronto: University of Toronto Press, 2017. 186 pp., \$24.95 paper (9781442629073)

Brooks, Abigail. Ways Women Age: Using and Refusing Cosmetic Intervention. New York: New York University Press, 2017. 278 pp., \$28.00 paper (9780814724057)

Conley, Dalton and Jason Fletcher. The Genome Factor: What the Social Genomics Revolution Reveals about Ourselves, Our History, and the Future. Princeton, NJ: Princeton University Press, 2017. \$35.00, 282 pp., hardcover (9780691164557)

Craddock, Susan. Compound Solutions: Pharmaceutical Alternatives for Global Health. Minneapolis: University of Minnesota Press, 2017. 184 pp., \$25.00 paper (9781517900793) 
Daly, Martin. Killing the Competition: Economic Inequality and Homicide. Herndon, VA: Transaction Publishers, 2017. 241 pp., \$24.95 paper (9781412863360)

De Vries, Gerard. Bruno Latour. Hoboken, NJ: Blackwell John Wiley, 2016. 221 pp., \$20.70 paper (9780745650630)

Dreilling, Michael C. and Derek Y. Darves. Agents of Neo-Liberal Globalization: Corporate Networks, State Structures, and Trade Policy. New York: Cambridge University Press, 2016. 297 pp. \$114.95 hardcover (9781107133969)

Dolgon, Corey and Tanja Mitchell. The Cambridge Handbook of Service Learning and Community Engagment. Cambridge and New York: Cambridge University Press, 2017. 554 pp., \$200.95 hardcover (9781107153783)

Gentile, Patrizia, Gary Kinsman, and L. Pauline Rankin (Eds). We Still Demand! Redefining Resistance in Sex and Gender Struggles. Vancouver: University of British Columbia Press, 2016. 307 pp., \$95.00 hardcover (9780774833349)

Guptill, Amy E., Denise A. Copelton, and Betsy Lucal. Food and Society 2E. Hoboken, NJ: Blackwell John Wiley, 2017. 250 pp., $\$ 29.95$ paper (9781509501847)

Helmes-Hayes, Rick and Marco Santoro (Eds). The Anthem Companion to Everett Hughes. London and New York: Anthem Press, 2016. 243 pp., \$115.00 hardcover (9780857281784)

Holmes, Mary. Sociology for Optimists. Thousand Oaks, CA: Sage, 2017. 169 pp., \$37.00 paper (9781446268681)

Iannelli, Laura. Hybrid Politics: Media and Participation. Thousand Oaks, CA: Sage, 2016. 134 pp., \$80.00 hardcover (9781473915787)

Joppke, Christian. Is Multiculturalism Dead? Crisis and Persistence in the Multicultural State. Hoboken, NJ: Blackwell John Wiley, 2016. 224 pp., \$29.95 paper (9780745692128)

Kaler, Amy. Baby Trouble in the Last Best West: Making New People in Alberta, 1905-1939. Toronto: University of Toronto Press, 2017. 190 pp., \$24.95 paper (9781442613942)

Kaspersen, Lars Bo and Jeppe Strandsbjerg (Eds). Does War Make States? Investigation of Charles Tilly's Historical Sociology. 
Cambridge and New York: Cambridge University Press, 2017. 333 pp. \$137.95 hardcover (9781107141506)

Kealey, Gregory. Spying on Canadians: The Royal Canadian Mounted Police Security Service and the Origins of the Long Cold War. Toronto: University of Toronto Press, 2017. 276 pp., \$29.95 paper (9781487521585)

Lee, Cheol-Sung. When Solidarity Works: Labor-Civic Networks and Welfare States in the Market Reform Era. New York: Cambridge University Press, 2016. 414 pp., \$137.95, hardcover (9781107174047)

Marks, Jonathan. Is Science Racist? Cambridge and Malden: Polity Press, 2017. 240 pp., \$15.95 paper (ISBN: 978-0-7456-8922-7)

Martell, Luke. Sociology of Globalization 2E. Hoboken, NJ: Blackwell John Wiley, 2016. 277 pp., \$34.95 paper (9780745689777)

Negri, Antonio. Marx and Foucault, Essays Volume I. Translated by Ed Emery. Hoboken, NJ: Blackwell John Wiley, 2017. 206 pp., $\$ 23.95$ paper (9781509503414)

Pernecky, Tomas. Epistemology and Metaphysics for Qualitative Research. Thousand Oaks, CA: Sage, 2016. 236 pp., \$49.00 paper (9781446282397)

Pickard, Susan. Age Studies: A Sociological Study of How we Age and are Aged Through the Life Cycle. Thousand Oaks, CA: Sage, 2017. 278 pp., \$44.00 paper (9781446287378)

Ragin, Charles C., and Peer Fiss. Intersectional Inequality: Race, Class, Test Scores, and Poverty. Chicago: University of Chicago Press, 2016. 173 pp., \$25.00 paper (97802264144099)

Roberts, Adrienne. Gendered States of Punishment and Welfare: Feminist Political Economy, Primitive Accumulation and the Law. London and New York: Routledge, 2016. 204 pp. \$145.00 USD hardcover (9781138678422), \$54.95 USD e-book (9781315542362)

Samson, Colin and Carlos Gigoux. Indigenous Peoples and Colonialism: Global Perspectives. Hoboken, NJ: Blackwell John Wiley, 2016. 252 pp., \$24.95 paper (9780745672526)

Schinkel, Willem. Imagined Societies: A Critique of Immigrant Integration in Western Europe. Cambridge and New York: Cam- 
bridge University Press, 2017. 271 pp., \$114.95 hardcover (9781107129733)

Spickard, James V. Alternative Sociologies of Religion: Through NonWestern Eyes. New York: New York University Press, 2017. 314 pp. \$27.00 paper (9781479866311), \$89.00 hardcover (9781479826636)

Stiegler, Bernard. Automatic Society: The Future of Work, Volume I. Hoboken, NJ: Blackwell John Wiley, 2017. 341 pp., \$31.95 paper (9781509506316)

Woodcock, Jamie. Working the Phones: Control and Resistance in Call Centers. Chicago: University of Chicago Press, 2017. 200 pp., \$90.00 hardcover (9780745399089), \$30.00 paper (9780745399065)

Wright, James D. Social Problems, Social Issues, Social Science: The Society Papers. New Brunswick, USA and London, UK: Transactions Publishers, 2016. 317 pp. \$34.95 paper (9781412865012)

Yazdani, Kevah. India, Modernity and the Great Divergence. Leiden: Brill, 2017. 669 pp., \$246.00 paper (9789004330788)

Zubrzycki, Geneviéve. Beheading the Saint: Nationalism, Religion and Secularism in Quebec. Chicago and London: University of Chicago Press, 2016. 224 pp., \$35.00 paper (9780226391687) 